\title{
Mathematical Modelling and Tray Drying Kinetics of Loquat (Eriobotrya japonica)
}

\author{
Anuradha Mishra, Neha Sharma
}

\begin{abstract}
The present study was aimed to investigate drying of loquat slices in tray dryer at different temperatures Drying was conducted at $45^{\circ} \mathrm{C}, 55^{\circ} \mathrm{C}$, and $65^{\circ} \mathrm{C}$ at constant air velocity of 0.5 $\mathrm{m} / \mathrm{s}$ in tray dryer;time taken for drying of slices was $12 \mathrm{~h}, 10 \mathrm{~h}$ and $9 \mathrm{~h}$ respectively. The analysed moisture data was fitted in four different drying mathematical models, i.e. Henderson and Pabis, Page, Logarithmic and Newton (Lewis).Statistical analysis predicted that Page model was best-fitted model for describing drying characteristics of loquat slices. Best-fitted model was selected by obtaining maximum value of regression coefficient $\left(R^{2}\right)$ and minimum value of chi square $(\chi 2)$ and root mean square error (RSME). It was observed that shrinkage percentage was less at higher temperature as compared to the lower temperature, i.e., $45^{\circ} \mathrm{C}$.
\end{abstract}

Keywords: loquat, tray drying kinetics, mathematical modelling

\section{I.INTRODUCTION}

Loquat is a seasonal fruit and a rich source of vitamin A and minerals [1].Being seasonal and perishable in nature decreases the shelf life of the fruit in the glut season. It has been reported that post-harvest losses of fresh loquat fruits in developing countries is $20-40 \%$ when compared with the developed countries [2], reduction in losses can be achieved by adopting suitable preserving process. Loquat contains 80 to $87 \%$ moisture and is very prone to post-harvest losses. To avoid these losses and improve the shelf-life of loquat, drying is one of the best alternative processes available to industry. The effect of various older drying methods like solar drying, etc. on loquat slices have been studied [3]. It is important to give attention to dehydration of tropical fruits for improving their storage life and market value. Drying of different fruits such as kiwi [4], banana [5], sapota [6], guava [7], pineapple [8], figs [9] and beetroot [10] etc. has been studied.

Heat and mass transfer phenomena are involved simultaneously during drying process. Drying of fruits is old and economical process of preservation; by using suitable methods of drying, it is possible to preserve original characteristics of fruits. During the drying process, removal of moisture up to certain limits $8-11 \%$ is necessary. At this moisture content, the microbial deterioration and physiochemical changes are minimized to a great extent [11].

Revised Manuscript Received on December 30, 2019.

* Correspondence Author

Anuradha Mishra, Amity Institute of Food Technology, Amity University Uttar Pradesh, Noida, India

Neha Sharma*, Amity Institute of Food Technology, Amity University Uttar Pradesh, Noida, India.

(C) The Authors. Published by Blue Eyes Intelligence Engineering and Sciences Publication (BEIESP). This is an open access article under the CC BY-NC-ND license (http://creativecommons.org/licenses/by-nc-nd/4.0/)
Many researchers have found that dehydration process maintains the food values and effectively inactivate the enzymes.There are many changes that occur during drying process in which some are desirable and others are undesirable. Effect on color, texture, flavour and chemical composition of products have also been reported[12].In order to reduce these undesirable changes, appropriate drying methods and temperature combinations are selected. According to FAO, one-third of the food that comes for the consumer is being spoiled every year [13].Kinetic study of all drying fruits cannot be represented by same manner due to complex phenomena of heat and mass transfer. Experimental drying study of uniform loquat slices was performed by using a tray dryer. The obtained data was analysed for moisture diffusivity, optimisation of the drying characteristics of slices, rehydration ratio and coefficient of rehydration to find out best-fit model. Four mathematical models were selected from literature for this study, i.e, Henderson and Pabis [14], Page [15], Logarithmic [16] and Newton (Lewis) [17]. They are listed in Table no.1along with their mathematical expression. The values of drying ratio, dehydration ratio, rehydration ratio and shrinkage of slices were calculated.

Dried fruit slices has gained the consumer acceptance because they are rich in nutrition and contains energy in concentrated form. Dried slices can be consumed with combination of any snacks, breakfast, rehydrated in milk or water, jam, ice-cream flavour, curd and yogurt.

This shows that drying is an excellent and economical method for increasing the applications of fruits and vegetables. Tray drying method and drying kinetics has not been employed in loquat till this time. Little research is available on loquat drying [3].

The present aim of this study is to find the best fit-model so as to know the appropriate time-temperature combination that retains the maximum nutritional, textural and sensory properties.

\section{MATERIALS AND METHODS}

\section{A. Raw material procurement}

Fresh ripe and fully mature "kandala" variety loquat were purchased from local market of Ghaziabad and Baghpat. Ripe loquats were thoroughly washed several times using distilled water in order to remove dust and other adhering foreign material. Fruits were then cut into two equal halves approx. $0.5 \mathrm{~cm}$. thickness, seeds were removed.

\section{B. Chemical Treatment}

Enzymatic reactions leads to oxidation on the cut surface of loquat slices and cause the fruit surface to turn brown in color. 
Inactivation of enzymes is necessary to cease such oxidation reaction and prevent browning. For the purpose of prevention of enzymatic browning, the sliced loquat were soaked in $1 \%$ potassium metabisulphite (KMS) solution for $10 \mathrm{~min}$.

\section{Tray Drying}

Pre-weighted samples were spread uniformly in trays for drying. Initial moisture content and water activity were analysed prior to drying. In order to study drying behaviour of slices, drying were conducted three different temperatures i.e. $45^{\circ} \mathrm{C}, 55^{\circ} \mathrm{C}$, and $65^{\circ} \mathrm{C}$, taking three reapplication in each temperature. Laboratory scale tray dryer (IK-112, New Delhi) at a uniform air velocity $0.5 \mathrm{~m} / \mathrm{s}$ was chosen for kinetic study of slices. The slices was weighted every one hour until constant weight is obtained.

\section{D.Processing Flow Chart}

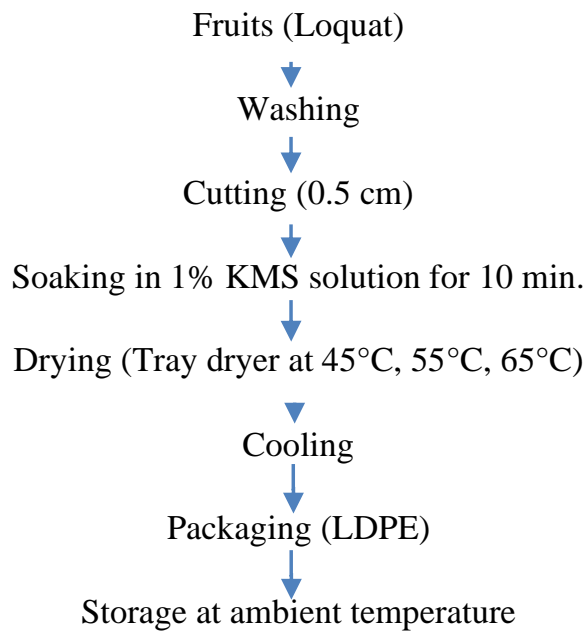

\section{E. Drying parameter}

Moisture content: Moisture content of dehydrated slices were determined by standard AOAC (1990) method. Approx. $5 \mathrm{~g}$ of sample were taken for moisture determination at 105 ${ }^{\circ} \mathrm{C}$ for $4 \mathrm{~h}$ until the constant value was attained. Moisture content was determined by following formula (1).

$$
(\mathrm{W} 1)-(\mathrm{W} 2)
$$

$$
\text { Moisture content }(\%)=-------------
$$

\section{Where, $W 1=$ Initial weight; $W 2=$ Final weight}

Drying Rate: Drying rate is defined as mass of unit of water removed per unit time. Drying rate was calculated by following formula:

$$
\text { Amount of water removed }
$$

$$
\text { DR = ----------------------------- }
$$

Dehydration Ratio: It is ratio of weight of sample before drying and weight of sample after drying. Dehydration ratio was calculated by following formula [18]:

$$
\text { Mass of slices before drying }
$$

Dehydration Ratio (DR) =

\section{Mass of slices after drying}

Shrinkage: Shrinkage is the deformation of sample dimensions after drying [19, 20]. It is ratio of final volume of dried sample to initial volume of sample. Following formula used for shrinkage determination:

Initial volume (V1) - Final Volume (V2)
Shrinkage $(\%)$ - ----------------------------

Rehydration Ratio (RR): To evaluate reconstitution property of dried loquat slices rehydration test was perform. Rehydration ratio of dried loquat slices was performed according to AOAC method. Take $5 \mathrm{~g}$ of each dehydrated sample in a separate beaker filled with water and allowed to absorb water at room temperature. After every 5 min. the sample weight was recorded until achieving equilibrium absorbance of water. Rehydration is process to restore the original properties of products. Ratio of water absorbed by sample to initial weight of dehydrated slices defines the rehydration ratio (eq. 5)

$$
\mathrm{RR}=\frac{\text { Weight of soaked sample }}{\text { Weight of sample before soaking }}
$$

Reconstitution Coefficient $=\frac{\text { RR }}{------}$

F. Modelling: Drying kinetics study is important to anticipate the water removal at any drying time from any food material. Drying data were analyse to find out best-fitted model and decided according to chi square, $\mathrm{R}$ square and RMSE value. RSME value shows the variation between experimental data and projection data and tend to achieve zero. Mathematical model having less Chi square and high $\mathrm{R}$ square value, are reported to be best fitted [21]. There are various models that are being used for drying kinetics some of the best ones that suits for tray drying study of loquat slices listed in Table 1. Moisture ratio (MR) was calculate by following formula

$\mathrm{MR}=\stackrel{\mathrm{M}_{1}}{\mathrm{M}_{2}}$

Where, $\mathrm{M}_{1}$ is moisture content in loquat slices at any time $\mathrm{t}$, and $\mathrm{M}_{2}$ is initial moisture content.

Table 1. List of Models applied for loquat thin layer drying

\begin{tabular}{|l|l|}
\hline Model name & Model equation \\
\hline Henderson and Pabis & $\mathrm{MR}=\mathrm{a} \exp \left(-\mathrm{kt}^{\mathrm{n}}\right)$ \\
\hline Page & $\mathrm{MR}=\exp \left(-\mathrm{kt}^{\mathrm{n}}\right)$ \\
\hline Logarithmic & $\mathrm{MR}=\mathrm{a} \exp (-\mathrm{kt})+\mathrm{c}$ \\
\hline Newton (Lewis) & $\mathrm{MR}=\exp (-\mathrm{k} . \mathrm{t})$ \\
\hline
\end{tabular}

For statistical analysis important three parameter were selected namely chi- square, RMSE and regression ratio. Statistical analysis was performed by using Origin Pro 8.5 software.

\section{RESULTS AND DISCUSSION}

\section{A. Drying Characteristics:}

Moisture content and Drying Time: Initial moisture content was determined to be $86 \%$ of fresh Loquat slices. It was observed that moisture content decrease with increasing drying time at different temperature (figure 1). It is clear from graph, reduction of moisture content follow falling rate period pattern during different drying temperatures.

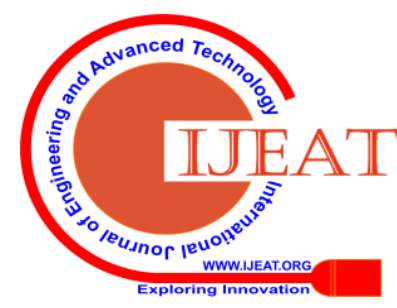


It was observed that final moisture content was approx.10\%, $9 \%$ and $8 \%$ at $45^{\circ} \mathrm{C}, 55^{\circ} \mathrm{C}$ and $65^{\circ} \mathrm{C}$ under tray dryer and time taken approx. 12 h, 10 h, 9 h respectively . Others scientists observed similar results on mushroom and bamboo slices [22, 23]. Graph revealed that the moisture content was initially high and then become slower until equilibrium moisture content was attained. The results were in accordance to the drying theory which shows that at high temperature water diffusion energy is high and rate of water removal also becomes high [24].

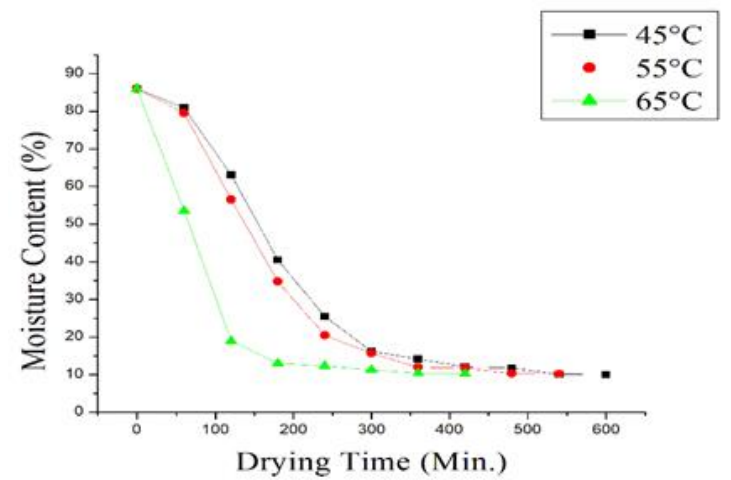

Fig 1. Graph of moisture content and drying time for loquat slices dried at three temperature

Drying Rate and moisture content:

Fig 2. shows the significant variations with drying rate and moisture content at $45^{\circ} \mathrm{C}, 55^{\circ} \mathrm{C}$, and $65^{\circ} \mathrm{C}$. Loquat slices were not following constant rate period like other similar products and resulted followed only falling rate period at 0.5 $\mathrm{m} / \mathrm{s}$ air velocity. Drying rate increased rapidly at initial stage and then becomes slower. Rate of drying is high during beginning stage because of high amount of moisture content but after some time rate of water removal decreased due to shrinkage of slice surface and low amount of moisture. Similar pattern of water removal was observed by many researchers in apple and cherry [25, 26].

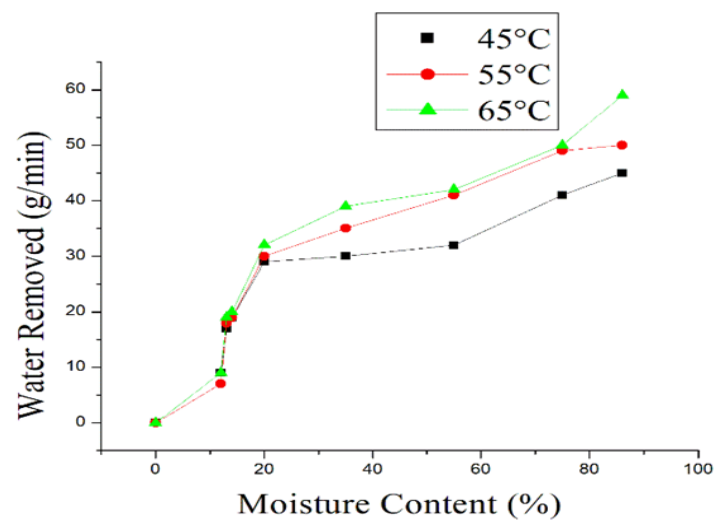

Fig 2. Graph of drying rate (DR) and drying time at different temperature

Rehydration and shrinkage study of loquat slices:

Relation of rehydration ratio and time of dehydrated loquat slices were reported in Fig 3. The graph indicated that the rehydration ratio was significantly affected by drying temperature. The rehydration ratio of loquat slices dried at $65^{\circ} \mathrm{C}$ indicated higher values than observed by other drying temperatures. At the higher temperature, highly porous structure was formed and less porous structure at lower drying temperature [27]. The rehydration data was analysed and observed that the amount of dehydrated samples dried at $65^{\circ} \mathrm{C}$ increased approximately four times. While after $30 \mathrm{~min}$ mass of rehydrated samples dried at $55^{\circ} \mathrm{C}$ and $45^{\circ} \mathrm{C}$ increased more than thrice. Obtained results agreed with rehydration of some foods [28]. Data of loquat slices shrinkage is presented in Table no 2. At higher temperature, $\left(65^{\circ} \mathrm{C}\right)$ shrinkage of loquat slices was reflected to be minimum and at $45^{\circ} \mathrm{C}$, shrinkage was maximum. These result agreed with carrot drying at different drying methods [29].

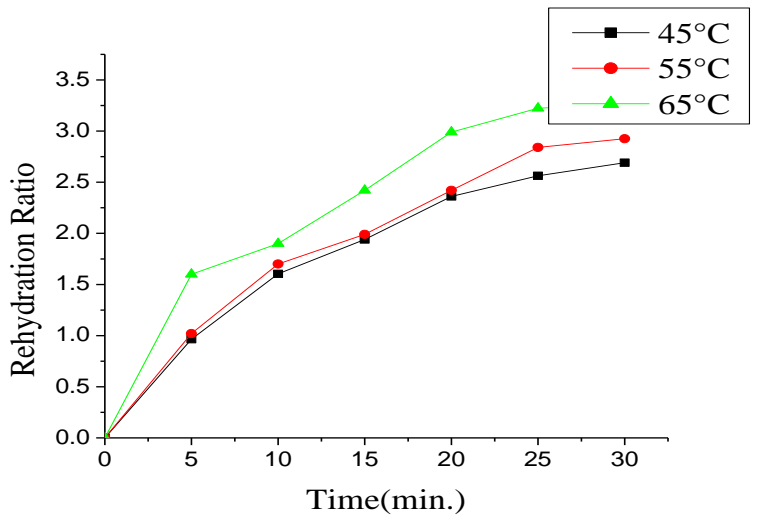

Fig.3 effect of drying temperature on Rehydration quality of dehydrated Loquat slices

Table 2. Shrinkage percentage of loquat slices at different temperature

\begin{tabular}{|l|l|l|}
\hline S. No. & Temperature $\left({ }^{\circ} \mathbf{C}\right)$ & Shrinkage (\%) \\
\hline 1 & 45 & 89.53 \\
\hline 2 & 55 & 88.44 \\
\hline 3 & 65 & 85.64 \\
\hline
\end{tabular}

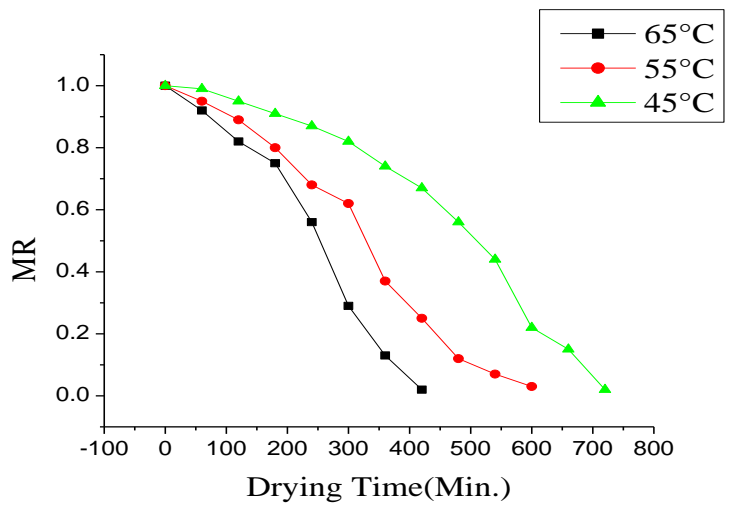

Fig 4. Plot of moisture ratio (MR) with drying time (min.) dried at three temperature.

Table 3. Model coefficient and drying constant at different temperature.

\begin{tabular}{|l|l|l|l|l|l|}
\hline $\begin{array}{l}\text { Name of } \\
\text { model }\end{array}$ & $\begin{array}{l}\text { Tempe } \\
\text { rature } \\
\text { C) }\end{array}$ & R2 & $\chi^{\circ}$ & RSME & Constant \\
\hline $\begin{array}{l}\text { Henderso } \\
\mathrm{n} \text { and }\end{array}$ & $45^{\circ} \mathrm{C}$ & 0.9454 & 0.0014 & 0.0101 & $\begin{array}{l}\mathrm{k}=0.00231 \\
\mathrm{a}=1.951 \\
\mathrm{k}=0.00512\end{array}$ \\
$\begin{array}{l}\text { Pabis } \\
\mathrm{MR}=\mathrm{a}(-\mathrm{kt})\end{array}$ & $55^{\circ} \mathrm{C}$ & 0.9531 & 0.0028 & 0.0462 & $\begin{array}{l}\mathrm{k}=1.931 \\
\mathrm{a}=1.93 \\
\mathrm{k}=0.0054 \\
\mathrm{a}=1.933\end{array}$ \\
\hline
\end{tabular}




\begin{tabular}{|c|c|c|c|c|c|}
\hline $\begin{array}{l}\text { Logarith } \\
\text { mic } \\
(\mathrm{MR}= \\
\text { a exp } \\
(-\mathrm{kt})+\mathrm{c})\end{array}$ & $\begin{array}{l}45^{\circ} \mathrm{C} \\
55^{\circ} \mathrm{C} \\
65^{\circ} \mathrm{C}\end{array}$ & $\begin{array}{l}0.9134 \\
0.9427 \\
0.9443\end{array}$ & $\begin{array}{l}0.0452 \\
0.0038 \\
0.0064\end{array}$ & $\begin{array}{l}0.1102 \\
0.0752 \\
0.0642\end{array}$ & $\begin{array}{l}\mathrm{a}=1.131 \\
\mathrm{k}=0.00554 \\
\mathrm{c}=-0.0042 \\
\mathrm{a}=1.154 \\
\mathrm{k}=0.0030 \\
\mathrm{c}=-0.0278 \\
\mathrm{a}=1.951 \\
\mathrm{k}=0.0034 \\
\mathrm{c}=0.0312\end{array}$ \\
\hline $\begin{array}{l}\text { Page } \\
(\mathrm{MR}= \\
\exp \\
\left.\left(-k t^{\mathrm{n}}\right)\right)\end{array}$ & $\begin{array}{l}45^{\circ} \mathrm{C} \\
55^{\circ} \mathrm{C} \\
65^{\circ} \mathrm{C}\end{array}$ & $\begin{array}{l}0.9973 \\
0.9934 \\
0.9978\end{array}$ & $\begin{array}{l}0.0004 \\
1 \\
0.0003 \\
9 \\
0.0001 \\
4\end{array}$ & $\begin{array}{l}0.0442 \\
0.0142 \\
0.0904\end{array}$ & $\begin{array}{l}\mathrm{k}=0.00048 \\
\mathrm{n}=1.85 \\
\mathrm{k}=0.00069 \\
\mathrm{n}=2.17 \\
\mathrm{k}=0.000371 \\
\mathrm{n}=2.12\end{array}$ \\
\hline $\begin{array}{l}\text { Newton( } \\
\text { Lewis) } \\
\text { (MR=exp } \\
\text { (-k.t)) }\end{array}$ & $\begin{array}{l}45^{\circ} \mathrm{C} \\
55^{\circ} \mathrm{C} \\
65^{\circ} \mathrm{C}\end{array}$ & $\begin{array}{l}0.8986 \\
0.9114 \\
0.9332\end{array}$ & $\begin{array}{l}0.0082 \\
0.0012 \\
0.0062\end{array}$ & $\begin{array}{l}0.1752 \\
0.0125 \\
0.0942\end{array}$ & $\begin{array}{l}\mathrm{k}=0.00441 \\
\mathrm{k}=0.0024 \\
\mathrm{k}=0.0074\end{array}$ \\
\hline
\end{tabular}

Model fitting: Moisture reduction data was collected from tray drying method and the moisture ratio was calculated respectively. A graph was plotted between moisture ratio and drying time at different drying temperatures which resulted in estimation of the the best-fitted thin layer drying model i. e. Henderson and Pabis, Page, Logarithmic and newton (Lewis). Statistical results obtained from all models was tabulated in Table no. 2. Different parameters were taken for estimation of best fitting of model including $\chi 2, \mathrm{R}^{2}$ and root mean square error (RSME). To obtain the values of all parameters non-linear regression was preferred. For goodness of fitting, $\mathrm{R}^{2}$ value should be high while $\chi 2$ and RMSE should be low. From all the model results, $\mathrm{R}^{2}$ value was estimated to be more than 0.89 and it is a good indication for curve fitting. From the result table the value of $\mathrm{R}^{2}, \chi^{2}$ and RMSE varied from 0.89 to $0.99,0.00039$ to 0.0452 and 0.0101 to 0.1752 respectively. Among all the mathematical models Page model was found best-fitted model of loquat slices at different temperature and securing average value of $\mathrm{R}^{2}$ (0.99), $\chi 2$ (0.00094) and RSME (0.1488).

\section{CONCLUSION}

The effect of different drying temperatures on drying time and loquat slices was analysed in this study. All the drying operations follow falling rate period. It was found that by increasing drying temperature, drying time decreases. The statistical results claimed that Page model is a best-fitted mathematical model. This model provided highest $\mathrm{R}^{2}$ and lowest $\chi 2$ and RSME for each temperature. Rate of shrinkage decreased upon increasing drying temperature. Minimum shrinkage was computed at $65^{\circ} \mathrm{C}(85.64 \%)$ and maximum shrinkage at $45^{\circ} \mathrm{C}$, low shrinkage slices are accepted for better quality products.

\section{REFERENCES}

1. MojtabaDelfanian,RezaesmaeilzadehKenari and Mohammad Ali Sahari, "Antioxidative effect of loquat (Eriobotrya japonica Lindl.) Fruit skin extract in soyabean oil", J.Food Science \& Nutrition, 2014.

2. Sirivatanapa, S, "Packaging and transportation of fruits and vegetables for better marketing", Asian Productivity Organization, Food, and Agriculture Organization of the United Nations, pp. 43-48,2006.
3. F. Samia El-Safy, "Drying Characteristics of Loquat Slices Using DifferentDehydration Methods by Comparative Evaluation", World Journal of Dairy \& Food Sciences, Vol. 9, no. 2,pp. 272-284, 2014.

4. Boris Huirem and Babu Ram Shakya, "Thin Layer Drying Kinetics Of Kiwifruits",Int.Journal of Science, Engineering and Technology Research, Vol.4, pp.5, 2015

5. Abano E. E. and Sam-Amoah L. K., "Effects of Different Pre-treatments on Drying Characteristics Of Banana Slices", Asian Research Publishing Network Asian Research Publishing Network ,Vol.6 no. 3, pp. 121-129, 2011.

6. Sachin V. Jangam,Varsha S. Joshi, Arun S. Mujumdar, and BhskarN.Thorat, "Studies on Dedydration of Sapota (Achraszapota)", J. Drying Technology, Vol. 26, pp. 369-377, 2008.

7. SnehaTripathi, John Diomond and Mayank Mishra, "Study on Drying and Quality Characteristics of Tray and Microwave Dried Guava Slices" ,Int. Journal of science \& engineering Research, Vol. 7, no. 10, pp. 965 - 970, 2016

8. L.A. Ramallo and R.H. Mascheroni, "Quality evaluation of pineapple fruit during drying process", Food and Bio products Processing, Vol 90. pp. 275-283, 2012.

9. Sara Ansari, NedaMaftoon-Azad, AsgarFarahnaky, Ebrahim Hosseini, and FojanBadii, "Effect of moisture content on textural attributes of dried figs",Int. Agrophys, Vol. 28, pp. 403-412, 2014.

10.D.Kamalakar,P.Rohinikumar and L.Nageswara Rao "Comparative Studies of Micro Wave Oven andTray Drying on Beetroot", Int. Journal for Innovative Research in Science \&Technology,Vol. 2, no.10,pp. 243-347, 2016

11.Marques, L.G., Silveira, A.M., Freire, J.T., “ Freeze-drying characteristics of tropical fruits" Drying Technology, Vol. 24, pp. 457-463, 2006

12.Farris, S., Gobbi, S., Torreggiani and D., Piergiovanni, L., "Assessment of two different rapid compression tests for the evaluation of texture differences in osmo-air-dried apple rings", Journal of Food Engineering, Vol. 88, p.p. 484-491,2008

13."Global food losses and food waste - Extent, causes and prevention". Rome. Retrieved from http://www.fao.org/docrep/014/mb060e/mb060e.pdf, FAO, 2011.

14.Henderson, S. M. and Pabis, S.,"Grain drying theory I. Temperature effect on drying coefficient", Journal of Agricultural Engineering Research, Vol.3, pp. 169-174, 1961.

15.Mohite, A.M. and Sharma, N.," Drying behaviour and engineering properties of lima beans", Agricultural Engineering International CIGR Journal, Vol. 20(3), pp. 80-185, 2018.

16.Yaldiz, O. and Ertekin, C.,"Thin layer solar drying of some vegetable", Journal of Drying Technology, Vol. 19, pp. 583-596, 2001.

17.Westerman, P. W., White, G. M. and Ross, I. J., "Relative humidity effect on the high temperature drying of shelled corn", Transactions of the ASAE, Vol. 16, pp.1136-1139, 1973.

18.Tune-Akintunde TY., "effect of soaking water temperature and time on some rehydration characteristics and nutrient loss in dried bell pepper", Agricultural engineering International, Vol.10, pp. 1-7, 2008.

19.Karathanos V.T., Kanellpoulos N.K and Belessiotis V.G., "Development of porous structure during air drying of agriculture plant products", Journal of Food Engineering, Vol.29, pp.167-183, 1996.

20.Marousis, S.N., Saravacos and G.D., "Density and porosity in drying starch materials", Journal of Food Science, Vol. 55, pp. 1367-1372, 1990.

21.Kaya A., Aydin O. andDemirtas C., "Drying kinetics of Red Delicious Apple",Journal of Bio systems engineering, Vol. 96, pp. 517524,2007

22.L. E. Kurozawa, P. M. Azoubel, F. E. X. Murr, and K. J. Park, "Drying kinetic of fresh and osmotically dehydratedmushroom(Agaricusblazei)," Journal of Food Process Engineering, vol. 35, no. 2, pp. 295-313, 2012.

23. P. S. Kumar, M. Kanwat, and V. K. Choudhary, "Mathematical modeling and thin-layer drying kinetics of bamboo slices on convective tray drying at varying temperature," Journal of FoodProcessing and Preservation, vol. 37, pp. 914-923, 2013.

24.Prabhanjan G, Ramaswamy S, Raghavan V. Microwave assisted convective air-drying of thin layer carrots. Journal of Food Engineering, Vol.25, p.p. 283, 1995.

25.Akpinar EK, Bicer Y and Midilli A. "Modelling and experimental study on drying of apple slices in a convective cyclone dryer", Journal of Food Process Eng., Vol. 26, p.p. 515-541,2003.

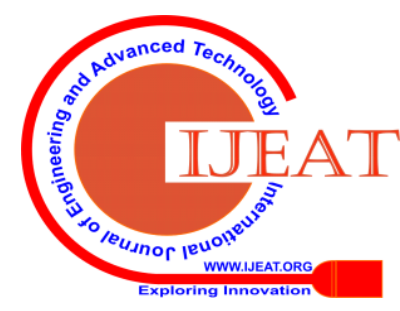


26.Tarhan S, Ergunes G, Taser,"Selection of chemical and thermal pre-treatment combination to reduce the dehydration time of sour cherry (Prunuscerasus L.)", Journal of Food Process Eng., Vol. 29, p.p. 651-663, 2006

27.Prachayawarakorn, S., W.Tia, N. Plyto and S.Soponronnarit, "Drying kinetics and quality attributes of low-fat banana slices dried at high temperature", Journal of Food Eng., Vol. 85,pp. 509-517, 2008.

28.LewickiP.P.,"Some remarks on rehydration of dried foods",Journal of Food Engineering,Vol.36,p.p. 81-87,1998.

29.M. S. Hatamipour and D. Mowla, "Shrinkage of carrots during drying in an inert medium fluidized bed,"Journal of FoodEngineering, vol. 55 , no. 3, pp. 247-252, 2002.

\section{AUTHORS PROFILE}

Anuradha Mishra has done M.Tech in food technology from SHIATS,Allahabad. She has more than 5 year teaching and research experience.Currently she is persuing Ph.D. in Food Technology.

Dr. Neha Sharma is working as Associate Professor at Amity University, Noida. She has more than 14 years of teaching and research experience in the field of Food Technology. 